\title{
Comparison of Calculated LDL-Cholesterol Using Various Formulae with Directly Measured LDL-Cholesterol: A Retrospective Study
}

\author{
Kruthi B N, Aliya Nusrath* \\ Department of Biochemistry, AIMS, B G Nagara-571448, Karnataka, India
}

Received October 23, 2020; Revised December 2, 2020; Accepted December 30, 2020

\section{Cite This Paper in the following Citation Styles}

(a): [1] Kruthi B N, Aliya Nusrath, "Comparison of Calculated LDL-Cholesterol Using Various Formulae with Directly Measured LDL-Cholesterol: A Retrospective Study," International Journal of Biochemistry and Biophysics, Vol. 8, No. 3, pp. 41 - 46, 2020. DOI: 10.13189/ijbb.2020.080301.

(b): Kruthi B N, Aliya Nusrath (2020). Comparison of Calculated LDL-Cholesterol Using Various Formulae with Directly Measured LDL-Cholesterol: A Retrospective Study. International Journal of Biochemistry and Biophysics, 8(3), 41 - 46. DOI: 10.13189/ijbb.2020.080301.

Copyright $\bigcirc 2020$ by authors, all rights reserved. Authors agree that this article remains permanently open access under the terms of the Creative Commons Attribution License 4.0 International License

\begin{abstract}
Background: Among the various risk factors for developing dyslipidemia and Cardiovascular Disease (CVD), elevated Low-Density Lipoprotein Cholesterol (LDL-C) has been recognized as an independent and widely accepted risk factor for CVD. Therefore the objective of the study was to calculate LDL-C using various formulae and to compare the various formulae to calculate LDL-C with direct LDL-C measurement. Materials and methods: It was a retrospective observational study and study was conducted for a period of 3 Months. During this period, 400 consecutive serum samples were included, out of which 37 had TG value more than $400 \mathrm{mg} / \mathrm{dl}$ and were excluded from the study. Finally 363 samples data were included for analysis and data were obtained from the investigation ledger of clinical Biochemistry section and same sample Triglyceride, Total Cholesterol and High Density Lipoprotein Cholesterol was used for calculating LDL-C using various formulae. Results: A total of 400 lipid profile reports were collected, of these, 37 reports had triglyceride level $\geq 400 \mathrm{mg} / \mathrm{dl}$ and hence 363 samples were included. There is no statistical difference between the direct LDL-C $(131.64 \pm 29.34 \mathrm{mg} / \mathrm{dl})$ and LDL-C level calculated by Friedewald formula $(133.85 \pm 35.97 \mathrm{mg} / \mathrm{dl}$, $\mathrm{p}>0.05)$. There is a highly significant statistical difference between the direct LDL-C and the LDL-C level calculated using all other formulae $(\mathrm{p}=0.0001)$ Cordova and Cordova formula $(88.06 \pm 28.40 \mathrm{mg} / \mathrm{dl})$, Vujovic formula $(80.44 \pm$
\end{abstract}

$15.52 \mathrm{mg} / \mathrm{dl})$, Ahmadi formula $(186.34 \pm 63.26 \mathrm{mg} / \mathrm{dl})$, Anandaraja formula $(92.46 \pm 32.37 \mathrm{mg} / \mathrm{dl})$, Puavillai formula $(88.54 \pm 32.78 \mathrm{mg} / \mathrm{dl})$ and Hattori formula $(77.45 \pm$ $30.31 \mathrm{mg} / \mathrm{dl})$. Conclusion: The study established Friedewald formula as the most suitable method for calculating LDL-C in the absence of direct LDL-C measurement facilities. A large sample size and multicentric study is warranted to confirm which formula is most suitable for measuring the LDL-C in the absence of direct LDL-C measurement.

Keywords Cardiovascular Disease, Direct Low-Density Lipoprotein Cholesterol, Calculated Low-Density Lipoprotein Cholesterol, Friedewald Formula

\section{Introduction}

Cardiovascular disease (CVD) is a group of disease of heart and blood vessels and it is one of the most common causes of morbidity and mortality worldwide. To identify the risk factors of CVD, lipid profile is done routinely as a screening test. It includes the estimation of Triglycerides (TG), Total Cholesterol (TC), High-density Lipoprotein Cholesterol (HDL-C), Low-density Lipoprotein Cholesterol (LDL-C) and Very low density Lipoprotein Cholesterol (VLDL-C).[1] 
Among the various risk factors for developing dyslipidemia and CVD, elevated LDL-C has been recognized as an independent and widely accepted risk factor for CVD.[1]

The National Cholesterol Education Programme (NCEP) Adult Treatment Panel III (ATP III) recommends a goal of maintaining serum LDL-C concentration $<100 \mathrm{mg} / \mathrm{dl}$ as optimal. Depending on the value of serum LDL-C, adults are grouped into various risk of developing heart disease if: LDL-C value is $100-129 \mathrm{mg} / \mathrm{dl}$ - Desirable Risk, LDL-C value is $130-159 \mathrm{mg} / \mathrm{dL}$-Borderline high-risk and LDL-C value is $\geq 160 \mathrm{mg} / \mathrm{dL}$ considered as High risk.[2]

In 1983 homogenous assays was developed for direct measurement of LDL-C. [3] In India this method is not routinely practiced in most of the laboratories because direct LDL-C estimation is expensive and time consuming. Hence, majority of the clinical laboratories measure LDL-C concentration in serum using Friedewalds formula by taking the concentration of TC, HDL-C and TG, with the help of formula LDL-C=TC-( HDL-C+TG/5). [4]

There are several shortcomings of Friedewalds formula, it cannot be used for LDL-C calculation when the patient is not in fasting, if serum TG $>400 \mathrm{mg} / \mathrm{dL}$ and in patients of hyperlipoproteinemia.[5] Despite these limitations, Friedewalds formula is still the most commonly used formula in clinical laboratories for measuring LDL-C concentration.[6]

Several other formulae have been proposed over the years for calculation of LDL-C. These are Cordova and Cordova [7] et al., Vujovic [8] et al., Ahmadi [9] et al., Anandaraja [10] et al., Puavillai [11] et al., and Hattori 12] et al., Similar to Friedewald's formula, these formulae also use TG, TC and HDL-C to calculate LDL-C. These formulae are not without the limitation. By considering this ambiguity in reporting, the present study was undertaken with the objectives to calculate LDL-C using various formulae and to compare with direct LDL-C assay, so as to obtain an acceptable formula at our setting in replacement for the direct measurement hence making lipid profile estimation cost effective.

\section{Material \& Method}

This was a retrospective observational study and study was initiated after obtaining approval from the Institutional Ethics Committee of Adichunchanagiri Institute of Medical Sciences (AIMS), B G Nagara. The fasting serum sample received at Biochemistry section of clinical Laboratory for estimating the lipid profile was analyzed using various enzymatic methods.

The data required for the present study was obtained from the investigation ledger of Biochemistry section of clinical Laboratory and same sample TG, TC and HDL-C was used for calculating LDL-C using various formulae.

The present study was carried out for a period of 3 Months. During this period a total 400 consecutive serum samples that were in the age group between 18-70 years, received in the clinical laboratory for estimating lipid profile were considered. Out of 400 samples, 37 had TG value more than $400 \mathrm{mg} / \mathrm{dl}$ and were excluded from the study. Finally 363 samples data were included for analysis.

Lipid profile was analyzed using standard methods such as TC was analyzed by cholesterol oxidase peroxidase method. TG was estimated by glycerol peroxidase peroxidase (GPO-PAP) method. HDL-C was analyzed by PEG - cholesterol esterase (direct enzymatic) method. The LDL-C assay was analyzed by cholesterol esterase cholesterol oxidase (homogeneous) method (Direct LDL-C).

LDL-C was also calculated by using various formulae by considering the values of TC, serum TG, HDL-C data from the investigation ledger.

\section{Various Formulae Used for Calculating LDL-C}

1. Friedewald [4] et al., LDL-C =TC-HDLC-(TG/5)

2. Cordova and Cordova [7] LDL-C $=3 / 4 \mathrm{x}$ (TC-HDL-C)

3. Vujovic [8] et al., LDL-C=TC-(TG/6.85)-HDLC

4. Ahmadi [9] et al., LDL-C=TC/1.19+TG/1.9-HDL-C/1.1

5. Anandaraja [10] et al., LDL-C $=0.9 \times T C-(0.9 \times T G / 5)-28$

6. Puavillai [11] et al., LDL-C=TC-HDL-C-(TG/6)

7. Hattori [12] et al., LDL-C $=0.94 \times$ TC-0.94xHDL-C-0.19xTG

The factor [TG] / 5 is an estimate of VLDL-C concentration, and is based on average ratio of TG to cholesterol in VLDL-C.

\section{Statistical Analysis}

Data were entered into Microsoft Excel sheet and analyzed using SPSSv15 software. Results are represented as mean \pm standard deviation. The statistical significance was evaluated at $95 \%$ confidence level and probability value $(\mathrm{p})$ of $<0.05$ was considered as statistically significant.

\section{Results}

Lipid profile data including direct LDL-C were obtained from the investigation ledger of Biochemistry section of clinical Laboratory retrospectively from past 3 months. A total of 400 lipid profile reports were included. Of these, 37 reports had triglyceride level $\geq 400 \mathrm{mg} / \mathrm{dl}$, and hence were rejected before final analysis.

The mean age distribution of the subject was $50.38 \pm 11.92$ years with male as $50.23 \pm 11.44$ years and female as $50.67 \pm 12.28$ years ( $p$ value $>0.05$ ). Figure 1 shows the distribution of male and female study population and the male to female ratio was 1.8:1. 


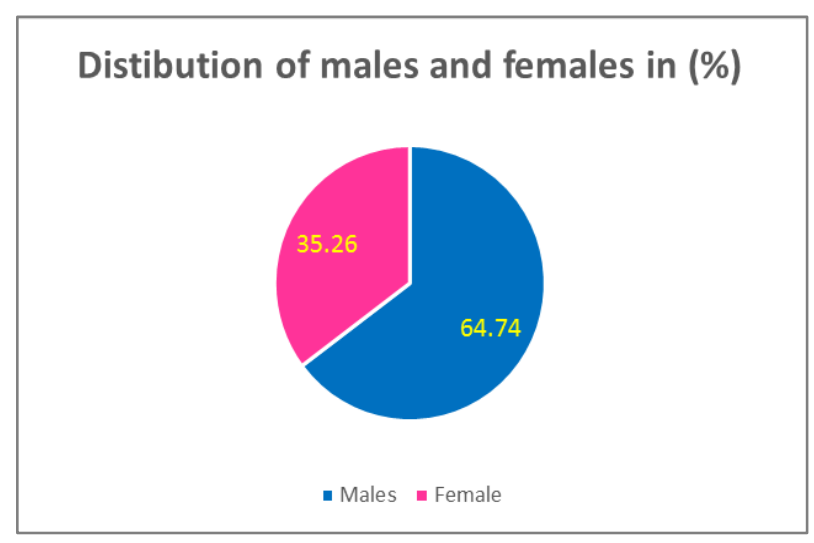

Figure 1. Male $(n=235)$ and female $(n=128)$ distribution of study population

The estimated lipid profile is as shown in table 1. The mean values of all parameters except triglycerides are within normal limits. However, the triglycerides mean values are borderline high.

Table 1. Lipid profile of the study population $(n=263)$

\begin{tabular}{|c|c|c|}
\hline Parameters & Mean & SD \\
\hline TC $(\mathrm{mg} / \mathrm{dl})$ & 168.50 & 41.78 \\
\hline TG $(\mathrm{mg} / \mathrm{dl})$ & 173.25 & 76.58 \\
\hline HDL-C $(\mathrm{mg} / \mathrm{dl})$ & 51.09 & 9.89 \\
\hline LDL-C $(\mathrm{mg} / \mathrm{dl})$ & 131.64 & 29.34 \\
\hline
\end{tabular}

Table 2 shows distribution of study Population having the normal and abnormal values of lipid profile. Majority of the study population were having total cholesterol $(74.38 \%)$ and HDL-C (85.39\%) in reference range. However more than half of the study population was having higher triglycerides (55.37\%) and another $78.78 \%$ of them were having LDL-C above reference range.
Table 2. Distribution of Proportion of lipid profile in the Study Population

\begin{tabular}{|c|c|c|c|}
\hline \multirow{2}{*}{ Parameters } & & $\begin{array}{c}\text { Number } \\
(\mathbf{n}=363)\end{array}$ & $\begin{array}{c}\text { Percentage } \\
(\mathbf{\%})\end{array}$ \\
\hline \multirow{2}{*}{$\mathrm{TC}(\mathrm{mg} / \mathrm{dl})$} & $<200 \mathrm{mg} / \mathrm{dL}$ & 270 & 74.38 \\
\cline { 2 - 4 } & $\geq 200 \mathrm{mg} / \mathrm{dL}$ & 93 & 25.62 \\
\hline \multirow{2}{*}{$\mathrm{TG}(\mathrm{mg} / \mathrm{dl})$} & $<150 \mathrm{mg} / \mathrm{dL}$ & 162 & 44.62 \\
\cline { 2 - 4 } & $\geq 150 \mathrm{mg} / \mathrm{dL}$ & 201 & 55.37 \\
\hline \multirow{2}{*}{$\begin{array}{c}\mathrm{HDL}-\mathrm{C} \\
(\mathrm{mg} / \mathrm{dl})\end{array}$} & $>40 \mathrm{mg} / \mathrm{dL}$ & 310 & 85.39 \\
\cline { 2 - 4 } & $\leq 40 \mathrm{mg} / \mathrm{dL}$ & 53 & 14.60 \\
\hline \multirow{2}{*}{$\begin{array}{c}\mathrm{LDL}-\mathrm{C} \\
(\mathrm{mg} / \mathrm{dl})\end{array}$} & $<100 \mathrm{mg} / \mathrm{dL}$ & 67 & 18.45 \\
\cline { 2 - 4 } & $\geq 100 \mathrm{mg} / \mathrm{dL}$ & 296 & 78.78 \\
\hline
\end{tabular}

Table $3 \&$ figure 2 shows the comparison of the estimated LDL-C (Direct LDL-C) levels with the calculated LDL-C values by various formulas. There is no statistical difference between the direct LDL-C and LDL-C levels calculated by Friedewald formula ( $p>0.05$ ). There is a highly significant statistical difference between the direct LDL-C and the LDL-C levels calculated using all other formulae $(\mathrm{p}=0.0001)$ except Friedewald formula. The LDL-C levels are overestimated when Ahmadi formula is applied whereas the values are underestimated by using the other formulae.

Table 3. Comparison of Direct LDL-C levels with the calculated LDL-C values by various formulas $(n=363)$

\begin{tabular}{|c|c|c|c|}
\hline $\begin{array}{c}\text { Formulas to calculate } \\
\text { LDL-C values }\end{array}$ & $\begin{array}{c}\text { Mean LDL-C } \\
\text { levels }(\mathbf{m g} / \mathbf{d l})\end{array}$ & SD & $\begin{array}{c}\mathbf{p} \\
\text { value }\end{array}$ \\
\hline Direct LDL-C & 131.64 & 29.34 & -- \\
\hline Friedewald formula & 133.85 & 35.97 & $>0.05$ \\
\hline Cordova and Cordova formula & 88.06 & 28.40 & 0.0001 \\
\hline Vujovic formula & 80.44 & 15.52 & 0.0001 \\
\hline Ahmadi formula & 186.34 & 63.26 & 0.0001 \\
\hline Anandaraja formula & 92.46 & 32.37 & 0.0001 \\
\hline Puavillai formula & 88.54 & 32.78 & 0.0001 \\
\hline Hattori formula & 77.45 & 30.31 & 0.0001 \\
\hline
\end{tabular}

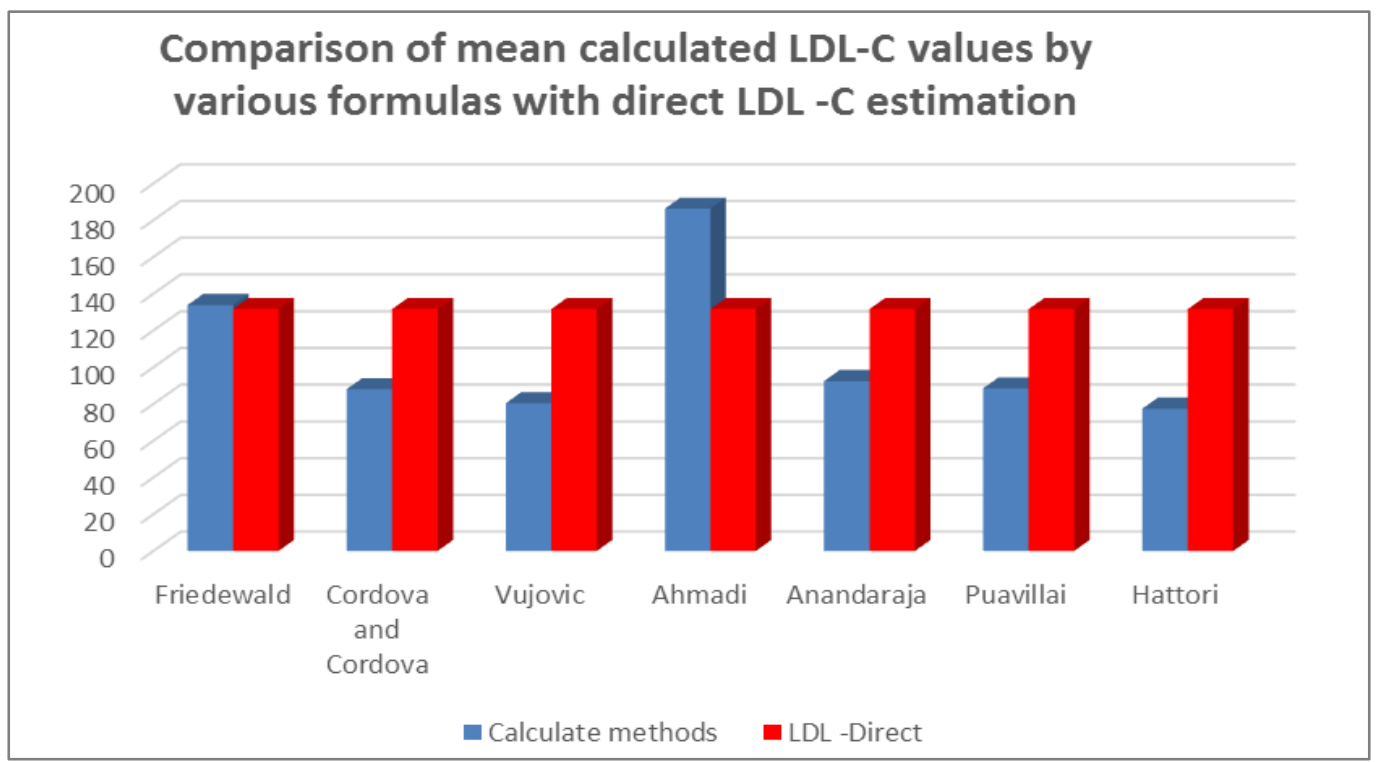

Figure 2. Comparison of Direct LDL-C levels with the calculated LDL-C values by various formulas $(n=363)$ 
A similar significance was also observed when comparison was done between the direct LDL-C and calculated LDL-C levels at different LDL-C ranges as shown in table 4.

Table 4. Comparison of Direct LDL-C with calculated LDL-C values at different LDL-C levels

\begin{tabular}{|c|c|c|c|c|c|c|c|c|}
\hline & \multirow{2}{*}{\multicolumn{2}{|c|}{$\begin{array}{c}\begin{array}{c}\text { LDL-C <100 mg\% } \\
\text { (Optimal range) }\end{array} \\
n=68\end{array}$}} & \multirow{2}{*}{\multicolumn{2}{|c|}{$\begin{array}{c}\begin{array}{c}\text { LDL-C between } 130 \text { - } 129 \\
\text { mg\% } \\
\text { (Desirable range) }\end{array} \\
\mathbf{n}=79\end{array}$}} & \multirow{2}{*}{\multicolumn{2}{|c|}{$\begin{array}{c}\begin{array}{c}\text { LDL-C between } 130 \text { - } 159 \\
\text { mg \% } \\
\text { (Borderline risk) }\end{array} \\
\mathrm{n}=171\end{array}$}} & \multicolumn{2}{|c|}{$\begin{array}{c}\text { LDL-C } \geq 160 \mathrm{mg} \% \\
\text { (High risk) }\end{array}$} \\
\hline & & & & & & & & \\
\hline & Mean \pm SD & p value & Mean \pm SD & $p$ value & Mean \pm SD & p value & Mean \pm SD & p value \\
\hline $\begin{array}{l}\text { LDL-C } \\
\text { Direct }\end{array}$ & $\begin{array}{c}84.87 \pm \\
13.11 \\
\end{array}$ & -- & $\begin{array}{c}113.27 \pm \\
8.84\end{array}$ & -- & $\begin{array}{c}148.7 \pm \\
5.94\end{array}$ & -- & $\begin{array}{c}167.89 \pm \\
10.18\end{array}$ & -- \\
\hline Friedewald & $\begin{array}{l}91.07 \pm \\
25.48\end{array}$ & 0.0767 & $\begin{array}{c}116.76 \pm \\
26.58\end{array}$ & 0.2698 & $\begin{array}{l}147.4 \pm \\
23.26\end{array}$ & 0.4964 & $\begin{array}{c}174.94 \pm \\
22.81\end{array}$ & 0.0588 \\
\hline $\begin{array}{c}\text { Cordova \& } \\
\text { Cordova }\end{array}$ & $\begin{array}{c}57.78 \pm \\
18.83 \\
\end{array}$ & $<0.0001$ & $\begin{array}{l}76.63 \pm \\
23.67 \\
\end{array}$ & $<0.0001$ & $\begin{array}{c}95.85 \pm \\
19.46 \\
\end{array}$ & $<0.0001$ & $\begin{array}{c}122.82 \pm \\
22.56\end{array}$ & $<0.0001$ \\
\hline Vujovic & $\begin{array}{c}61.68 \pm \\
10.79 \\
\end{array}$ & $<0.0001$ & $\begin{array}{c}74.28 \pm \\
12.31 \\
\end{array}$ & $<0.0001$ & $\begin{array}{c}86.55 \pm \\
10.87 \\
\end{array}$ & $<0.0001$ & $\begin{array}{c}95.66 \pm \\
9.41 \\
\end{array}$ & $<0.0001$ \\
\hline Ahmadi & $\begin{array}{c}136.56 \pm \\
47.83 \\
\end{array}$ & $<0.0001$ & $\begin{array}{c}172.39 \pm \\
59.88 \\
\end{array}$ & $<0.0001$ & $\begin{array}{c}195.59 \pm \\
53.40 \\
\end{array}$ & $<0.0001$ & $\begin{array}{c}248.42 \pm \\
59.63 \\
\end{array}$ & $<0.0001$ \\
\hline Anandaraja & $\begin{array}{l}53.96 \pm \\
22.93\end{array}$ & $<0.0001$ & $\begin{array}{c}77.08 \pm \\
23.92\end{array}$ & $<0.0001$ & $\begin{array}{l}104.71 \pm \\
20.94\end{array}$ & $<0.0001$ & $\begin{array}{c}129.45 \pm \\
20.52\end{array}$ & $<0.0001$ \\
\hline Puavillai & $\begin{array}{c}53.38 \pm \\
23.47 \\
\end{array}$ & $<0.0001$ & $\begin{array}{c}73.72 \pm \\
25.57 \\
\end{array}$ & $<0.0001$ & $\begin{array}{c}98.68 \pm \\
22.69 \\
\end{array}$ & $<0.0001$ & $\begin{array}{c}127.48 \pm \\
24.27 \\
\end{array}$ & $<0.0001$ \\
\hline Hattori & $\begin{array}{l}45.44 \pm \\
22.38\end{array}$ & $<0.0001$ & $\begin{array}{l}63.60 \pm \\
23.43\end{array}$ & $<0.0001$ & $\begin{array}{l}86.93 \pm \\
21.46 \\
\end{array}$ & $<0.0001$ & $\begin{array}{c}112.58 \pm \\
22.33\end{array}$ & $<0.0001$ \\
\hline
\end{tabular}

Mean value of lipid profile and calculated LDL-C using various formulae did not show gender wise difference and it was found to be statistically insignificant as shown in table 5.

Table 5. Gender wise comparison of lipid profile

\begin{tabular}{|c|c|c|c|c|c|}
\hline \multirow{2}{*}{} & \multicolumn{2}{|c|}{ Male (n=235) } & \multicolumn{2}{c|}{ Female (n= 128) } & Mean \\
\cline { 2 - 6 } & Mean & SD & 50.67 & 12.78 & p value \\
\hline Age & 50.23 & 11.44 & 170.55 & 40.50 & 0.73 \\
\hline TC & 167.38 & 42.51 & 168.92 & 76.20 & 0.50 \\
\hline TG & 175.61 & 76.85 & 51.98 & 9.94 & 0.43 \\
\hline HDL-C & 50.60 & 9.85 & 132.65 & 29.53 & 0.20 \\
\hline LDL-C & 131.09 & 29.28 & 33.78 & 15.24 & 0.63 \\
\hline TG/5 & 35.12 & 15.37 & 136.76 & 33.73 & 0.43 \\
\hline Friedewald & 132.26 & 37.11 & 88.92 & 27.71 & 0.26 \\
\hline Cordova and Cordova & 87.59 & 28.82 & 81.63 & 15.10 & 0.67 \\
\hline Vujovic & 79.80 & 15.74 & 184.96 & 63.16 & 0.23 \\
\hline Ahmadi & 187.08 & 63.44 & 95.09 & 30.36 & 0.76 \\
\hline Anandaraja & 91.04 & 33.40 & 90.41 & 31.36 & 0.26 \\
\hline Puavillai & 87.51 & 33.54 & 31.07 & 28.88 & 0.42 \\
\hline Hattori & 76.41 & & & 0.38 \\
\hline
\end{tabular}




\section{Discussion}

The study compared several formulae including Friedewald formula with direct LDL-C measurement. The measurement of LDL-C level is considered as a predictor for assessing the risk of various cardiac diseases and for treatment of dyslipidemias. Even though various formulae have been developed to calculate the LDL-C, most of the laboratories use Friedewald formula as the choice of formula to calculate LDL-C but many studies have shown its limitation and some have shown that other equations perform better for certain groups of populations.

The important finding of present study is that LDL-C level calculated using Friedewald formula did not show statistical significant difference with the directly measured LDL-C. But the LDL-C levels are overestimated when Ahmadi formula is applied whereas the values are underestimated by using the other formulae except Friedewald formula as seen in Table 3 \& Graph 2.

The present study results are in concurrence with the study done by Niranjan et al. In this study on comparison of Anandaraja Formula and Friedewald Formula with Direct LDL-C measurement, they concluded that Friedewald formula showed a strong correlation (0.876) in comparison with Anandaraja formula (0.844). [13]

In another study by Nishtha Wadhwa [14] et al., it was concluded that in Indian Population, Vujovic formula appears to be more accurate than any other formula. Whereas in another study conducted by Mugdha Dilip Garule [15] et al, it was reported that, Puavillai formula is the most accurate formula to calculate LDL-C at TG levels up to $150 \mathrm{mg} / \mathrm{dL}$ and also at all TG levels studied whereas Friedewald's formula is the best at TG levels between 151 to $199 \mathrm{mg} / \mathrm{dL}$ and Anandaraja formula at TG 200 to $399 \mathrm{mg} / \mathrm{dL}$.

However in the present when the comparison was done even at different levels of LDL-C (ie optimal level, desirable level, borderline and high-risk level), calculated LDL-C using Freidewald formula did not show significant difference whereas the other formulae showed significant difference with Ahmadi formula overestimating and others formulae the underestimating the LDL-C values at all levels of LDL-C as shown in table 4.

Farideh Razi [16] et al in a study suggested calculation of LDL-C based on Friedwald and Chen formula can be a good alternative for direct measurement especially in regions with limited resources. This study results are in concurrence with our study results. In our study we found that compared to other formulas, LDL-C calculated using Friedewald formula correlates better with direct LDL-C.

\section{Conclusions}

To conclude, the study established Friedewald formula as the most suitable method for calculating LDL-C in the absence of direct LDL-C measurement facilities. The limitation of the present study is small ample size and comparison was not done at different levels of triglyceride including when triglyceride levels were greater than $\geq 400$ $\mathrm{mg} / \mathrm{dl}$. A large sample size and multicentric study is warranted to confirm which formula is most suitable for measuring the LDL-C in the absence of direct LDL-C measurement.

Further the authors propose to continue future studies comparing the usefulness of these formulae in calculating LDL-C when triglycerides are $\geq 400 \mathrm{mg} / \mathrm{dl}$ which is considered as a limitation when Friedewald formula is applied.

\section{REFERENCES}

[1] Sidney C. SmithJr, Emelia J. Benjamin, Robert O. Bonow, Lynne T. Braun, Mark A. Creager, Barry A. Franklin, Raymond J. Gibbons, Scott M. Grundy, Loren F. Hiratzka, Daniel W. Jones, Donald M. Lloyd-Jones, Margo Minissian, Lori Mosca, Eric D. Peterson, Ralph L. Sacco, John Spertus, James H. Stein and Kathryn A, Taubert, "AHA/ACCF secondary prevention and risk reduction therapy for patients with coronary and other atherosclerotic vascular disease: 2011 update: a guideline from the American Heart Association and American College of Cardiology Foundation, Circulation, "Vol. 124, no. 22. pp. 2458-2473, 2011. https://doi.org/10.1161/CIR.0b013e318235eb4d.

[2] National Cholesterol Education Program (NCEP) Expert panel, "Third report of the National Cholesterol Education Program (NCEP) Expert panel on detection, evaluation and treatment of high cholesterol in adults (Adult Treatment Panel III) final report Circulation, " vol.106, no. 25, pp. 3143-421, 2002. https://doi.org/10.1161/circ.106.25.3143.

[3] Centers for Disease Control and Prevention. Cholesterol Reference Method Laboratory Network (CRMLN) [Internet] Atlanta (GA): Centers for Disease Control and Prevention; [cited 2016 August]. Available from: http://www.cdc.gov/la bstandards/crmln_clinical.html.

[4] William T Friedewald, Robert I Levy, Donald S Fredrickson, "Estimation of the concentration of low-density lipoprotein cholesterol in plasma, without use of the preparative ultra centrifuge," Clin Chem, Vol. 18, no. 6. pp. 499-502, 1972. https://doi.org/10.1093/clinchem/18.6.499.

[5] Rifai N, Warnick GR, "Measurement of lipids, lipoproteins, and apolipoproteins, " In: Burtis CA, Ashwood ER, Bruns DE, eds. Tietz Textbook of Clinical Chemistry and Molecular Diagnosis, (4th ed.) St. Louis, Missouri: Elsevier Saunders, 2006, $938-952$.

[6] Executive summary of the third report of the National Cholesterol Education Programme (NCEP) Expert panel on detection, evaluation, and treatment of high blood cholesterol in adults (Adult Treatment Panel III). JAMA, vol. 285, no. 19, pp. 2486-2497, 2001. DOI: 10.1001/jama.285.19.2486.

[7] Cordova CM, Cordova MM, "A new accurate simple formula for LDL-cholesterol estimation based on directly measured lipids from a large cohort," Ann Clin Biochem, vol. 
50, pp. 13-19, 2013. DOI: 10.1258/acb.2012.011259.

[8] Vujovic A, Jelena Kotur-Stevuljevic, Slavica Spasic, Nada Bujisic, Jelena Martinovic, Milica Vujovic, Vesna Spasojevic-Kalimanovska, Aleksandra Zeljkovic, Dragoljub Pajic, "Evaluation of different formulas for LDL-C calculation, " Lipids Health Dis, vol. 9, pp. 27-35, 2010. Doi: https://doi.org/10.1186/1476-511X-9-27.

[9] Ahmadi SA, Boroumand MA, Moghaddam KG, Tajik P, Dibaj SA, "The impact of low serum triglycerides on low density lipoprotein cholesterol estimation, " Arch Iranian Med, vol.11, pp. 318-21, 2008.

[10] Anandaraja S, Narang R, Godeswar R, Laksmy R, Talwar KK, "Low density lipoprotein cholesterol estimation by a new formula in Indian population, " International Journal Cardiology, vol. 102, no.1 pp.117-20, 2005. https://doi.org/10.1016/j.ijcard.2004.05.009.

[11] Puavillai W, Laorugpongse D, "Is calculated LDL-C by using the new modified Friedewald equation better than the standard Frieldewald equation, " J Med Assoc Thai, vol. 87, no.6, pp. 589-93, 2004.

[12] Y Hattori, M Suzuki, M Tsushima, M Yoshida, Y Tokunaga, Y Wang, D Zhao, M Takeuchi, Y Hara, K I Ryomoto, M Ikebuchi, H Kishioka, T Mannami, S Baba, Y Harano, "Development of approximate formula for LDL-cholesterol, LDL-apo B and LDLchol/LDL-apo B as indices of hyperapobetalipoproteinemia and small dense LDL,". Atherosclerosis, vol. 138, no. 2, pp. 289-99, 1998. Doi:

\subsection{6/s0021-9150(98)00034-3.}

[13] Niranjan Singh, BJ Pradeep Kumar, KV Thimmaraju, K Kalyan Kumar, Bindu Sharma, Ajai Kumar, "Anandaraja formula or friedewald formula, which is a better formula for calculating LDL cholesterol in comparison with direct LDL - measurement by homogenous assay method, International Journal of Contemporary Medical Research, vol. 4, no. 1, pp. 229-231, 2017.

[14] Nishtha Wadhwa, Radhika krishnaswamy, "Comparison of LDL-Cholesterol Estimate using Various Formulae with Directly Measured LDL Cholesterol in Indian Population," Journal of Clinical and Diagnostic Research, vol. 10, no.12, pp. BC11-BC13, 2016. DOI: 10.7860/JCDR/2016/22272.90 18.

[15] Mugdha Dilip Garule, Pravin Narayan Baravkar, Shilpa Aditya Pratinidhi, "Comparison of LDL-cholesterol estimated by various formulae with directly measured LDL-cholesterol in a tertiary care centre of Maval Taluka," International Journal of Clinical Biochemistry and Research, vol.5, no.4, pp. 583 - 587, 2018. DOI: 10.18231/2394-6377 .2018 .0124 .

[16] Farideh Razi, Katayoon Forouzanfar, Fatemeh Bandarian and Ensieh Nasli-Esfahani. "LDL-cholesterol measurement in diabetic type 2 patients: a comparison between direct assay and popular equations," Journal of Diabetes \& Metabolic Disorders, pp. 16-43, 2017. DOI 10.1186/s40200 -017-0326-2. 